АНАЛІЗ СТАНУ ПРАКТИКИ ЩОДО ФОРМУВАННЯ ІНФОРМАЦІЙНО-КОМУНІКАЦІЙНИХ КОМПЕТЕНТНОСТЕЙ В УЧНІВ З ІНТЕЛЕКТУАЛЬНИМИ ПОРУШЕННЯМИ НА УРОКАХ ІНФОРМАТИКИ

\title{
ANALYSIS OF THE PRACTICE OF FORMING INFORMATION AND COMMUNICATION COMPETENCES OF PUPILS WITH INTELLECTUAL DISORDERS IN INFORMATICS LESSONS
}

Стаття присвячена основним аспектам формування інформаційно-комунікаційних компетентностей в учнів на уроках інформатики у практиці спеціальної загальноосвітньої школи. Проведено аналіз досліджень у психолого-педагогічній та спеціальній літературі щодо питання використання інорормаційних технологій школярами. Досліджено різні погляди на науково-педагогічні проблеми інсрорматизації та комп'ютеризації навчального процесу спеціальних шкіл. З'ясовано, що підготовка вчителів спеціальних навчальних закладів щодо використання комп'ютерних засобів нині стоїть дуже гостро $і$ потребує особливої уваги. Визначено, що питання формування інфрормаційно-комунікаційних компетентностей в учнів з інтелектуальними порушеннями залишається практично не розробленим. Звернено увагу на те, що досліджувана проблема безпосередньо пов'язана із завданнями соціалізації школярів, оскільки без наявності в них певних знань із галузі інформатики стає неможливим їхнє повноцінне існування в сучасному суспільстві. Проаналізовано навчальні програми 3 інорорматики для спеціальних загальноосвітніх навчальних закладів та педагогічну практику вчителів. Визначено, наскільки педагоги розуміють важливість фрормування інформаційно-комунікаційних компетентностей в учнів із вадами інтелекту. Окреслено основні труднощі, які виникають у вчителів у процесі роботи, спрямованої на формування інорормаційно-комунікаційних компетентностейушколярів. Установлено, що використання інформаційних технологій дає змогу модернізувати і підвищити якість навчання, а також інтерес учнів до оволодіння базовими знаннями 3 інсрорматики. З'ясовано, що в прочесі фрормування інфрормаційно-комунікаційних компетентностей школярі зазнають суттєвих труднощів у зв'язку з ї психофрізичними особливостями. Обірунтовано необхідність перегляду і вдосконалення педагогічних методів $і$ засобів формування цих компетентностей в учнів спеціальної загальноосвітньої школи.

Ключові слова: інсрормаційно-комунікаційні компетентності, учні з інтелектуальними порушеннями, інформатика, комп'ютерні технології, спеціальна загальноосвітня школа.

The article deals with the main aspects of the formation of information and communication competences in pupils. The experience gained in computer science lessons in the practice of a special comprehensive school. The analysis of researches in the psycho-pedagogical and special literature conducted. The use of information technologies by pupils clarified. Different views was investigate on scientific and pedagogical problems of informatization and computerization of educational process of special schools investigated. In the article found that the training of special education teachers for the use of computer technologies is very acute today and needs special attention. It determined that the issue of formation of information and communication competences of pupils with intellectual disabilities remains practically not developed. The main attention is focused that the problem under study directly related to the tasks of socialization of pupils. Because without their certain knowledge in the field of informatics it becomes impossible for them to exist fully in modern society. Informatics training programs for special educational institutions and pedagogical practice of teachers analyzed. It determined how teachers understand the importance of developing information and communication competences of pupils with intellectual disabilities. The main difficulties encountered by teachers in the process of work aimed at the formation of information and communication competences of pupils outlined. The article found that the use of information technologies makes it possible to modernize and improve the quality of training. It also increases pupils' interest in acquiring basic knowledge of computer science. Besides, it found that in the process of formation of information and communication competences, pupils have trouble due to their psychophysical characteristics. The necessity to review and improve the pedagogical technologies of forming these competences of the pupils of special school substantiated.

Key words: information and communication competences, pupils with intellectual disabilities, computer science, computer technologies, special comprehensive school.
Постановка проблеми у загальному вигляді. Нині педагогічні колективи спеціальних загальноосвітніх шкіл в Україні стоять на шляху розв'язання питань: як і в якому обсязі фрормувати інорормаційно-комунікаційні компетентності в учнів 3 інтелектуальними вадами; наскільки робота 3 комп'ютером підвищує їхню працездатність, сприяє зосередженню уваги і збільшує темп виконання низки навчальних завдань. Безумовно, особливості психофрізичного розвитку учнів цієї категорії зумовлюють своєрідність їх навчання. 
Аналіз останніх досліджень і публікацій. Різні погляди на проблему інорорматизації і комп'ютеризації навчального процесу спеціальних шкіл висвітлено у працях Н. Глазкової, О. Кутепової, О. Легкого, С. Миронової, Ю. Сакуліної, С. Трикоз та ін. $[1 ; 4 ; 5 ; 7]$. При цьому науковці розглядають два аспекти:

- можливості використання комп'ютера як засобу навчання;

- доцільність і можливість навчання учнів 3 інтелектуальними порушеннями комп'ютерної грамоти.

О. Качуровська і М. Шеремет наголошують, що використання комп'ютерних програм у навчальному процесі спеціальної школи сприяє індивідуальнодиференційованому підходу. Але впровадження інорормаційних технологій можливе лише за умови створення якісних україномовних навчально-корекційних програмних засобів, адаптованих до застосування в умовах спеціального навчального закладу, розроблення та суттєвого удосконалення підходів щодо використання комп'ютерних технологій у навчальному процесі [3; 8].

Н. Глазкова мету навчання учнів з інтелектуальними порушеннями інформатики бачить у формуванні в них, передусім, інсрормаційних знань і умінь, які є доступними та необхідними для життя в сучасному інсрормаційному суспільстві, а також для розуміння перетворень, які в цьому суспільстві відбуваються [1].

С. Трикоз зазначає, що «...комп'ютерні технології, такі як мультимедійні навчальні презентації, навчальні програми, що стимулюють наочнообразне мислення й формують повноцінні наочні уявлення засобами анімаційної графріки, сприяють розвитку пізнавальної активності дитини, фрормуванню пошукової діяльності, вихованню упевненості у власних силах» [7, с. 100].

На думку вчених (О. Качуровська, О. Легкий, С. Миронова, М. Шеремет та ін.), на черзі гостро стоїть питання підготовки й перепідготовки педагогів спеціальних навчальних закладів щодо використання комп'ютерних технологій у корекційному навчанні [6].

Узагальнення проведених напрацювань щодо зазначеної проблеми у спеціальній педагогіці показує, що питання фрормування інфрормаційнокомунікаційних компетентностей в учнів з інтелектуальними порушеннями 3 урахуванням їх сутності, основних змістових складників, показників прояву та добору відповідних педагогічних напрямів, засобів і шляхів впливу залишаються практично не розробленими.

Виділення невирішених раніше частин загальної проблеми. Теоретичний аналіз досліджуваної проблеми показує, що труднощі їі розв'язання пов'язуються, передусім, зі станом навчання, невизначеністю відповідних педаго- гічних технологій, які передбачають дидактикометодичне, змістове та організаційне забезпечення фрормування інформаційно-комунікаційних компетентностей у школярів та добір відповідних методів та прийомів. Відповідно, всі ці аспекти відображаються на фрормуванні інфрормаційнокомунікаційних компетентностей в учнів спеціальної загальноосвітньої школи. Без наявності певних знань і навичок у галузі інсрорматики стає неможливим їх пристосування до життя у суспільному просторі після закінчення школи. Ці знання також потрібні у процесі набуття учнями професійної кваліфрікації, оскільки майже всі завдання у сучасному світі вирішуються на підставі використання комп'ютерних засобів. Також інсрормаційно-комунікаційні компетентності мають безпосередній вихід на розв'язання завдань соціалізації школярів взагалі, що є дуже актуальним і спонукає до розгляду означеної проблеми.

Мета статті - вивчення стану педагогічної практики щодо забезпечення срормування інсрормаційно-комунікаційних компетентностей в учнів 3 інтелектуальними порушеннями на уроках інфрорматики. Отримана інсрормація сприятиме накресленню основних напрямів і шляхів роботи педагогічних колективів.

Виклад основного матеріалу. Вивчення стану практики проводилося на підставі спостережень за навчальним процесом на уроках інсрорматики у спеціальних загальноосвітніх школах, за роботою учнів на уроках та аналізу їхньої діяльності, аналізу навчально-методичної літератури, проведення бесід із педагогами.

При цьому основна увага приділялась:

- визначенню, наскільки навчальні програми і плани навчальної роботи, підручники і методичні посібники націлюють педагога на роботу 3 формування інформаційно-комунікаційних компетентностей в учнів;

- виявленню, наскільки завдання, які виконують учні на уроках інфрорматики сприяють фрормуванню в них цих компетентностей, впливають на їхню підготовку до самостійного життя в сучасному суспільстві;

- визначенню, наскільки педагоги розуміють важливість фрормування інсрормаційно-комунікаційних компетентностей в учнів із вадами інтелекту;

- вивченню досвіду роботи педагогів на уроках інформатики в умовах спеціальної загальноосвітньої школи;

- визначенню основних труднощів, які виникають у педагогів у процесі організації роботи, спрямованої на фрормування інсрормаційно-комунікаційних компетентностей в учнів.

Під час аналізу навчальних програм з інсрорматики для спеціальних загальноосвітніх навчальних закладів простежувалась відповідність змісту 
навчально-методичного супроводження цілям завданням фрормування інфрормаційно-комунікаційних компетентностей в учнів 3 інтелектуальними порушеннями. Було встановлено, що на уроках інформатики учні отримують певний обсяг знань, важливих для елементарного користування комп'ютерною технікою, але вони є недостатніми для входження в сучасний соціум. Наголошується на тому, що учні $з$ вадами розумового розвитку погано орієнтуються в просторі, не вміють знаходити і запам'ятовувати об'єкти на ілюстраціях, картинах. Тому особливого значення набуває використання розвиваючих комп'ютерних ігор. Однак не вказано, які саме комп'ютерні ігри можна застосовувати на уроках і як саме.

Як показав аналіз програм з інформатики для старших класів, при вивченні цього предмета передбачена послідовна і системна робота, спрямована на набуття школярами досвіду практичних вправ, відповідних знань і особливо умінь і навичок. Водночас передбачається вивчення лише стандартних комп'ютерних програм операційної системи Windows та пакету прикладних програм Microsoft Office, що не повноцінно спрямовано на фрормування інфрормаційно-комунікаційних компетентностей в учнів 3 інтелектуальними порушеннями. Також школярі здебільшого обмежені в набутті практичного досвіду через специфічні матеріально-технічні умови їхнього навчання. Не сприяє цьому й застосування на уроках в основному словесних методів роботи.

Як показала педагогічна практика, використання комп'ютера в навчальному процесі спеціальних шкіл спрямоване переважно на розв'язання певних дидактичних завдань, при цьому комп'ютер використовується як допоміжний інструмент засвоєння додаткової інфрормації, інструкцій, демонстрацій матеріалу тощо. Характерними є застосування на деяких уроках імітаційно-моделюючих програм, навчальних комп'ютерних програм, але цей процес здійснюється здебільшого хаотично та безсистемно. На думку педагогів, нові освітні інформаційні технології дають змогу значно підвищити ефективність навчання.

Також невід'ємною складовою частиною ефективності навчального процесу $€$ компетентності педагогів в інфрормаційно-комп'ютерній сфрері. Вона включає не тільки впевнені навички користування комп'ютером, а й розроблення навчальнометодичних матеріалів, створення особливої взаємодії між вчителем та учнем на уроці. На жаль, все ще залишається недостатньою кількість вчителів, які використовують сучасні інфрормаційні та комп'ютерні засоби у своїй діяльності.

Спираючись на відповіді педагогів, можна стверджувати, що процес формування досліджуваних надбань на уроках інфрорматики йде в учнів зі значними труднощами. Як відомо, у більшості школярів із вадами інтелекту присутні деякі порушення моторики. Причому вони характеризуються різним ступенем складності - від паралічів до незначного порушення дрібної моторики кисті руки. Це суттєво ускладнює процес виконання практичних завдань за допомогою технічних засобів навчання і впливає на темп оволодіння навичками роботи з комп'ютерною технікою, зокрема користуванням клавіатурою і мишкою.

Слід зазначити, що під час упровадження інфрормаційно-комунікаційних технологій (IKT) у спеціальній школі необхідно враховувати особливості психіки дітей із вадами інтелекту, насамперед, ті, що можуть ускладнити роботу з технікою. Це, зокрема, підвищена втомлюваність, розосереджена увага, сповільнений темп сприймання інфрормації, тривале входження в процес роботи.

Оскільки застарілі методи та засоби навчання не враховують тенденції стрімкого розвитку науково-технічного прогресу і не відповідають сучасним вимогам уроку, це підштовхує вчителів до пошуку інноваційних методів навчання, якими якраз $€$ електронні засоби, та їх використання в навчальному процесі, спонукає до необхідності розроблення та втілення сучасних навчальнокорекційних програм, які будуть адаптовані до умов спеціальної школи та пошуку й опанування навчально-методичної літератури щодо цієї проблеми. Перегляду підлягають наявні підходи щодо використання комп'ютера на уроках інформатики. Оновлені програми, на думку педагогів, дають змогу суттєво покращити рівень інорорматичних знань і навичок у школярів спеціальної школи.

Зі слів педагогів, назріла гостра необхідність у фрахівцях комп'ютерного профрілю, які мають забезпечити створення ефективної системи допомоги учням із порушеннями інтелекту щодо фрормування в них інформаційно-комунікаційних компетентностей: усвідомлення їх значущості, визначення особливостей організації і методичного супроводу в умовах спеціальної школи. Ці функції має взяти на себе педагог, який добре розуміється на проблемі формування інформаційно-комунікаційних компетентностей в учнів 3 інтелектуальними порушеннями, розбирається і вільно володіє сучасними засобами IKT, має певну мотивацію та бажання постійно вдосконалювати свої професійні навички. До речі, останнім часом вирішенню цього питання приділяється значна увага під час підготовки майбутніх фрахівців відповідного профрілю: у підготовку корекційних педагогів включено курс «Інформаційні технології та технічні засоби корекційного навчання», що спрямовано на вчителя нового типу, який вільно володіє комп'ютерними засобами [2].

Отже, аналіз результатів бесід зі вчителів інорорматики засвідчує необхідність суттєвого розроблення теоретичних і практичних питань фрор- 
мування інформаційно-комунікаційних компетентностей в учнів з інтелектуальними порушеннями.

Висновки. Аналіз стану практики щодо забезпечення фрормування інорормаційно-комунікаційних компетентностей в учнів 3 інтелектуальними порушеннями на уроках інорорматики дає підстави зробити висновок щодо суттєвих труднощів їх формування в умовах спеціального навчального закладу. Для спеціальної школи принципово необхідними стають взаємодія і співпраця педагогівпрофесіоналів, які розуміють важливість, сутність і напрями формування інформаційно-комунікаційних компетентностей у школярів із вадами інтелекту в умовах сучасного процесу інорорматизації. Необхідним стає й певний педагогічний досвід оволодіння вчителями комп'ютерною грамотністю. Одержані дані підтвердили припущення про необхідність надання теоретичної і методичної допомоги педагогічному колективу спеціальних загальноосвітніх шкіл щодо визначення, роз'яснення і уточнення певних теоретичних і практичних положень фрормування інформаційно-комунікаційних компетентностей в учнів. Практика спеціальної загальноосвітньої школи свідчить про гостру необхідність перегляду і вдосконалення напрямів і змісту формування досліджуваних компетентностей у школярів з урахуванням сучасних положень нової концепції спеціальної освіти.

\section{БІБЛІОГРАФІЧНИЙ СПИСОК:}

1. Глазкова Н.Н. Обучение элементам инорорматики старших школьников с недоразвитием интеллекта : автореф. дис. ... канд. пед. наук / Рос. гос. пед. ун-т им. А.И. Герцена. Санкт-Петербург, 2007. 22 c

2. Дегтяренко Т.М. Поширення ідей упровадження інорормаційно-комунікаційних технологій у систему спеціальної освіти. Інфрормаційні технології $і$ засоби навчання. 2015. Том 46. № 2. URL: http://journal.iitta.gov.ua/index.php/itlt/article/viewFile/ 1207/917 (дата звернення: 25.09.2019).

3. Качуровська О. Новітні засоби корекції та розвитку мовлення учнів із тяжкими вадами мови. Дефректологія. 2006. № 2. С. 46-49.

4. Легкий О.М. Організаційно-педагогічні умови використання комп'ютера у спеціальній школі : автореф. дис. ... канд. пед. наук / ІН-т дефректології АПН України. Київ, 2001. 16 с.

5. Миронова С.П. Використання комп'ютера у корекційному навчанні дітей з вадами інтелекту. Десректологія. 2003. № 3. С. 41-44.

6. Савінова Н.В. Інформаційно-комунікаційні технології в корекційній освіті. Науковий часопис. Корекційна педагогіка. 2015. С. 156-163.

7. Трикоз С. Використання комп'ютерних технологій у навчанні дітей з порушеннями інтелектуального розвитку. Цифрова компетентність сучасного вчителя нової української школи : збірник тез доповідей учасників всеукр.наук.-практ. семінару, Київ, 12 березня 2019 р. / за заг. ред. О.В. Овчарук. Київ : Інститут інформаційних технологій і засобів навчання НАПН України, 2019. С. 99-100.

8. Шеремет М.К. Сучасні комп'ютерні технології в логопедичній роботі / М.К. Шеремет, Г. Загурська. Педагогіка та методики: Спеціальні / під ред. B.І. Бондар. Нац. пед. ун-т ім. М.П. Драгоманова. Київ, 2001. С. 183-192. 